\title{
Pelatihan Keterampilan Dasar Komputer dan Teknologi Informasi Di Sekolah Dasar Negeri 3 Munduk
}

\author{
Ida Bagus Kresna Sudiatmika, Ketut Queena Fredlina, Ni Luh Putu Ning Septyarini \\ Putri Astawa \\ Sekolah Tinggi Manajemen Informatika dan Komputer (STMIK) \\ Primakara, Bali, Indonesia
}

\begin{abstract}
ABSTRAK
Memahami teknologi sejak dini sangat baik dilakukan dikarenakan cepatnya laju perkembangan teknologi menjadikan kita untuk mempelajari teknologi. Komputer menjadi peran yang sangat penting bagi Pendidikan dikarenakan di era ini seluruh informasi bisa diakses dari computer melalui jaringan internet. Selain computer dapat digunakan sebagai saran informasi, computer juga dapat digunakan sebagai alat administrasi yang sangat penting pada Pendidikan dikarenakan seluruh pembuatan tugas siswa dapat dikerjakan dengan cepat dengan computer. Salah satu program yang dapat digunakan adalah Microsoft Office. Salah satu cara meningkatkan pengetahuan mengenai penggunaan Microsoft Office adalah pelatihan. Pelatihan ini dilaksanakan di Sekolah Dasar Negeri 3 Munduk dengan tujuan untuk melengkapi keterampilan peserta dalam mengoperasikan Microsoft office, adapun pelatihan yang dilakukan adalah Microsoft Word dan Microsoft Excel.
\end{abstract}

Kata Kunci : Microsoft Word, Microsoft Excel, Pelatihan.

\section{PENDAHULUAN}

Komputer merupakan salah satu media elektronik yang sangat digemari di era ini, banyak hal yang dapat dilakukan dengan komputer (Permana \& Mahameruaji, 2018). Selain itu, keterampilan dalam penggunaan komputer atau literasi digital juga sangat menentukan keberhasilan seseorang dalam hal pendidikan. Selain itu jika dilihat dari segi media pembelajaran, banyak media pembelajaran yang bisa dijalankan melalui penggunaan komputer dengan mengimplementasikan aplikasi tertentu (Putri, 2019). Seiring dengan berkembangnya ilmu pengetahuan dan IPTEK sehingga memiliki dampak bertambahnya sumber belajar dan media yang sangat praktis digunakan. Namun ada beberapa kendala yang terjadi saat ini, tidak semua orang terutama peserta didik bisa menggunakan komputer dengan baik dan benar. Banyak yang belum mengetahui manfaat komputer dalam menyelesaikan tugas. Dengan adanya hal tersebut maka dilakukan pengabdian masyarakat dengan memberikan pelatihan komputer dasar di SD Negeri 3 Munduk, Kecamatan Sukasada, Kabupaten Buleleng, Bali. Adapun permasalahan saat ini yang dihadapi oleh siswa SD Negeri 3 Munduk adalah siswa jarang menggunakan bahkan ada yang tidak pernah menggunakan komputer dikarenakan banyak dari mereka yang tidak memiliki komputer pribadi dan kurangnya ketersediaan komputer di sekolah mereka. Saat ini penggunaan komputer hanya digunakan oleh guru. Hal serupa juga ditemukan oleh Sahelatua, Vitoria \& Mislinawati pada penelitiannya tahun 2018 yang menemukan bahwa salah satu kendala penggunaan komputer/internet di Indonesia adalah kurangnya fasilitas yang ada.

Kegiatan pengabdian ini bertujuan untuk mengasah kemampuan siswa/siswa SD Negeri 3 Munduk dalam menggunakan computer. Dalam hal ini, pelatihan yang diberikan adalah Microsoft Word dan Microsoft Excel. Program ini dipilih karena pada umumnya mereka dapat melakukan pengolahan kata dasar dengan menggunakan Microsoft word dan pengolahaka 
angka (perhitungan dasar) di Microsoft Excel, ini disesuaikan dengan kebutuhan siswa/siswi di SD Negeri 3 Munduk. Pelatihan pengenalan Ms. Word sebagai pengolah kata, diharapkan melalui pelatihan ini dapat mempermudah siswa-siswi SD N 3 Munduk dalam melakukan pengolahan kata. Indikator capaian dari kegiatan ini adalah untuk mengasah kemampuan siswa-siswi SD Negeri 3 Munduk dalam menggunakan Ms. Word serta siswa dapat menggunakan Ms.Word untuk mempermudah proses pembelajaran. Pelatihan Ms. Excel sebagai pengolah angka bertujuan agar siswa-siswa SD Negeri 3 Munduk dapat menggunakan Ms.Excel untuk melakukan perhitungan yang diterapkan di sekolah tersebut diamana nantinya dapat mempermudah mereka dalam pembelajaran khususnya yang berkaitan dengan pengolahan angka.

\section{METODE PELAKSANAAN}

\section{Metode Penerapan Kegiatan}

Metode pelaksanan kegiatan pengabdian kepada masyarakat ini diuraikan dalam beberapa tahapan. Adapun alur pelaksanaan kegiatan ini dapat dilihat pada Gambar 1.

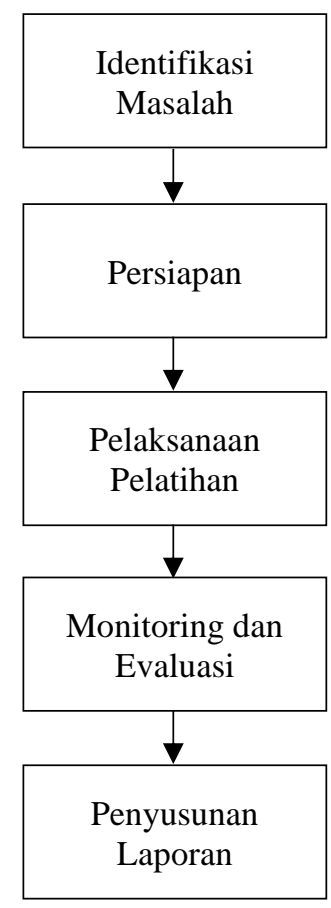

Gambar 1. Alur Pelaksanaan

a. Identifikasi Masalah

Dalam hal ini penulis merumuskan permasalahan yang terjadi di SD Negeri 3 Munduk khususnya yang terkait dengan pembelajaran computer di sekolah tersebut.

b. Persiapan 
Penulis mengumpulkan tim dan menyusun materi terkait dengan pelatihan computer dasar di SD Negeri 3 Munduk. Selain itu persiapan yang dilakukan juga terkai dengan hardware software yang disediakan.

c. Pelaksanaan Pelatihan

Pelaksanaan pelatihan dilaksanakan dalam 3 kali pertemuan seperti berikut :

i. Pertemuan pertama, peserta diberikan informasi terkait dengan pentingnya penggunaan computer dalam kegiatan pembelajaran sekaligus memotivasi peserta agar tekun mengikuti pelatihan nantinya.

ii. Pertemuan Kedua, peserta di berikan pelatihan untuk menggunakan Ms. Word. Adapun pelatihan yang diberikan adalah membuat paragraph, membuat table, membuat tulisan dengan berbagai variasi, serta memasukkan gambar dan bagaimana menyimpan dokumen. iii. Pertemuan Ketiga, peserta diberikan pelatihan untuk menggunakan Ms. Excel. Adapun pelatihan yang diberikan adalah menggunakan operasi dasar penjumlahan, pengurangan pembagian dan perkalian dengan menggunakan Ms. Excel.

c. Monitoring dan Evaluasi

Tahap evaluasi yang dilakukan adalah dengan memberikan tes disetiap akhir kegiatan untuk mengetahui kemampuan siswa dalam memahami pelatiahan yang diberikan.

d. Penyusunan laporan

Penyelesaian laporan sebagai bentuk pertanggung jawaban terhadap pelaksanaan pengabdian masyarakat di SD Negeri 3 Munduk.

\section{Peserta Pengabdian}

Peserta yang ikut dalam kegiatan pengabdian pada masyarakat ini adalah siswa SDN 3 Munduk. Sekolah Dasar Negeri 3 Munduk berlokasi di Banjar Dinas Tamblingan, Munduk, Kecamatan Banjar, Kabupaten Buleleng, Bali.

\section{HASIL DAN PEMBAHASAN}

\section{Hasil Kegiatan}

Aktivitas pertama yang dilakukan dalam pelatihan ini adalah melakukan sosialisasi kepada peserta pelatiahan. Sosialisasi ini bertujuan untuk meningkatkan motivasi peserta untuk mau mengikuti pelatihan. Selain itu sosialisasi memberikan informasi mengenai contoh hasil dari pengolahan kata dan pengolahan angka. Demi meningkatkan antusias peserta, disampaikan pula kemudahan dari penggunaan Ms. Word dan Ms. Excel. 


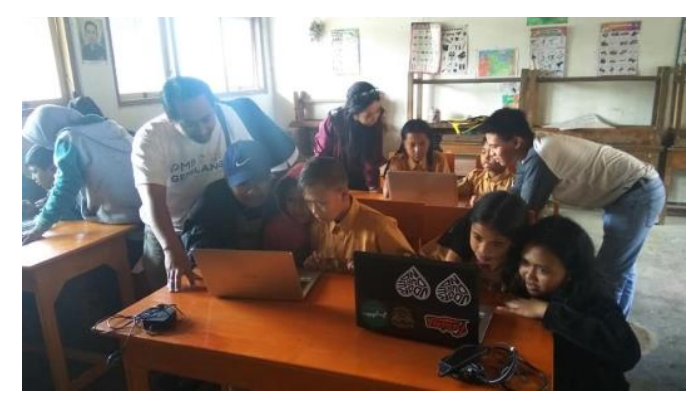

Gambar 2. Sosialisasi di SD N 3 Munduk

Kemudian terdapat langkah-langkah yang dilakukan berikutnya adalah melakukan pelatihan Microsoft Word. Adapun tahapan yang dilakukan adalah sebagai berikut:

a. Pengenalan Menu di Ms. Word

Ada beberapa menu yang terdapat di Ms. Word sehingga agar peserta memahami lebih jelas mengenai fungsi dari masing-masing menu maka disini narasumber mejelaskan mengenai fitur yang terdapat di masing-masing menu.

b. Pelatihan mengatur Text, Font dan Penataan halaman Dokumen

Setelah pengenalan fitur dan menu yang ada di Ms. Word, dilanjutkan dengan melakukan pelatihan pembuatan paragraph serta melakukan penataan text.

c. Penggunaan Table

Pelatihan berikutnya adalah penggunaan table, peserta diminta untuk membuat table dan dilakukan pelatihan untuk mengatur table dan memanipulasi table.

d. Penyimpanan Dokument

Setelah peserta mengerjakan tugas yang diberikan maka peserta dilatih untuk menyimpan dokumen melalui proses penyimpanan di Ms. Word. Kemudian dilakukan proses buka dokumen kembali.

Selanjutnya, terdapat beberapa langkah yang dilakukan berikutnya adalah melakukan pelatihan Ms. Excel. Adapun pelatihan yang dilakukan untuk Ms. Excel adalah sebagai berikut:

a. Pengenalan Menu

Pengenalan menu dan fitur yang ada di Ms. Excel bertujuan agar peserta didik dapat mengetahui fungsi dari masing-masing fitur.

b. Pelatihan Aritmatika Dasar

Pelatihan yang dilaksanakan adalah melaksanakan pelatihan untuk aritmatika dasar. Ini bertujuan untuk melatih peserta agar dapat memecahkan permasalahan artimatika (penjumlahan, pengurangan, perkalian dan pembagian) yang sering peserta temukan saat pembelajaran di sekolah.

\section{Penyelesaian Masalah}

Seluruh rangkaian kegiatan yang dilaksanakan mulai dari penyuluhan, pelatihan, serta monitoring/evaluasi yang akan dilaksanakan oleh tim pelaksana dapat terlaksana dengan baik. Dapat disimpulkan bahwa tingkat efektivitas pelatihan berkisar daro 80\%-90\%. Konteks tingkat efektivitas didasarkan atas keberhasilan pelatihan yang telah menyelesaikan tes yang diberikan. 
Selain itu juga dilakukan evaluasi peningkatan peningkatan kemampuan peserta melalui hasil kesesuaian hasil dengan contoh yang diberikan. Hasil evaluasi ini dilakukan untuk melihat hasil akhir yang di dapat dari pelatihan yang telah dilakukan.

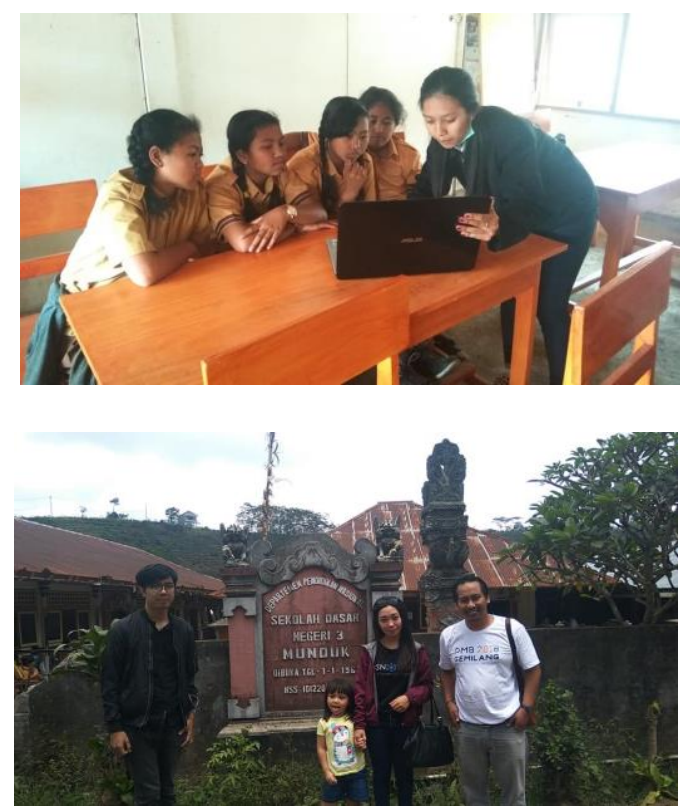

Gambar 3. Pelaksanaan Pengabdian

\section{KESIMPULAN DAN SARAN}

Pelaksanaan kegiatan pelatihan keterampilan dasar komputer dan teknologi informasi di SD Negeri 3 Munduk sudah terlaksana dan peserta pelatihan sudah mampu menggunakan Ms. Word dan Excel dengan baik. Dalam pelaksanaannya juga diketahui bahwa kegiatan ini mendapatkan tanggapan yang sangat baik dari peserta. Hal ini dapat dilihat dari perilaku peserta yang menujukan ketertarikan terhadap materi dengan cacra aktif bertanya dan menjawab pertanyaan dari pemateri. Selain itu, keberhasilan kegiatan ini dibuktikan dari tes yang diberikan diakhir kegiatan yang menunjukan adanya peningkatan keterampilan para peserta pelatihan dalam penggunaan Ms. Word dan Ms. Excel.

Diharapkan kedepannya pelatihan serupa dapat diberikan agar dapat meningkatkan keterampilan peserta didik di Indonesia dalam menggunakan aplikasi teknologi tertentu seperti Ms. Word atau Ms. Excel. Hal ini bertujuan untuk menciptakan generasi muda Indonesia yang lebih cakap dalam penggunaan teknologi sehingga berguna sebagai bekal untuk menghadapi era globalisasi. 


\section{DAFTAR PUSTAKA}

Permana, R. S. M., \& Mahameruaji, J. N. (2018). Strategi Pemanfaatan Media Baru Net. Tv Utilization Of New Media Strategy Of NET TV. Jurnal Studi Komunikasi Dan Media, 23 (1).

Putri, N. L. P. N. S. (2019). Buku Cerita Fabel Berbasis Pendidikan Karakter Untuk Siswa Sekolah Dasar Kelas Tinggi. Jurnal Lentera Pendidikan Pusat Penelitian LPPM UM Metro, 4(2), 126-143.

Sahelatua, L. S., Vitoria, L., \& Mislinawati, M. (2018). Kendala Guru Memanfaatkan Media It Dalam Pembelajaran Di Sdn 1 Pagar Air Aceh Besar. Jurnal Ilmiah Mahasiswa Pendidikan Guru Sekolah Dasar, 3(2). 